Zbigniew Szczerbowski ${ }^{1}$

ORCID: 0000-0002-2398-559X

Rafał Gawałkiewicz ${ }^{2}$

ORCID: 0000-0003-4261-1697

\title{
THE APPARENT DISPLACEMENT METHOD AS A TOOL IN LEVELING DATA PROCESSING APPLIED FOR VALIDATED DETERMINATION OF GROUND DEFORMATION
}

\author{
${ }^{1}$ AGH University of Science and Technology, Faculty of Mining Surveying and Environmental Engineering, Krakow, Poland \\ szczerbo@agh.edu.pl \\ ${ }^{2}$ AGH University of Science and Technology, Faculty of Mining Surveying and Environmental Engineering, Krakow, Poland \\ gawalkie@agh.edu.pl
}

Keywords: precise leveling, vertical displacements, data adjustments, apparent displacement method

\begin{abstract}
Area of Inowrocław town is considered as tectonically active due to halotectonic movement of salt dipair situated there. The geodetic surveys carried out for the determination of terrain surface deformations over the years revealed characteristics of the movement. The evaluated vertical displacements based on measurements of benchmarks show different characteristics, depending on distant points assumed as reference benchmarks. This raises problems in analysis, interpretation of the results and decision makings in master planning. The authors demonstrate a method of adjustment calculations that minimize the inconsistencies between previously elaborated heights and inconsistencies of points considered as stabile benchmarks. Thanks to the new approach the point considered as reference were recognized as unstable. And for the others more consistent values of the displacements were obtained: several benchmarks demonstrated higher difference of displacement values in compare to the initial approach in adjustments ranging in the interval of $-9 \mathrm{~mm}-+3 \mathrm{~mm}$.
\end{abstract}

\section{METODA PRZEMIESZCZEŃ POZORNYCH JAKO NARZĘDZIE W PRZETWARZANIU DANYCH NIWELACYJNYCH DLA WIARYGODNEGO WYZNACZANIA DEFORMACJI POWIERZCHNI TERENU}

Słowa kluczowe: niwelacja precyzyjna, przemieszczenia pionowe, wyrównanie danych, metoda przemieszczeń pozornych

\section{Abstrakt}

Obszar Inowrocławia uznawany jest za aktywny tektonicznie ze względu na halotektoniczny ruch znajdującego się tam wysadu solnego. Badania geodezyjne przeprowadzone w celu określenia powierzchni terenu na przestrzeni lat ujawniły charakterystykę tego ruchu. Oszacowane przemieszczenia pionowe na podstawie pomiarów niwelacyjnych sieci reperów wykazują różne charakterystyki w zależności od rodzaju przyjętych nawiązań dalekich punktów. Rodzi to problemy w analizie, interpretacji wyników i podejmowaniu decyzji w planowaniu głównym. Dlatego autorzy przedstawiają metodę wyrównania, która minimalizuje niespójności pomiędzy wcześniej opracowanymi wysokościami oraz niespójności punktów wcześniej uznanych za punkty 
nawiązania. Dzięki nowej metodzie punkty przyjęte wcześniej jako punkty nawiązania okazały się niestabilne. Natomiast dla innych reperów uzyskano bardziej spójne wartości przemieszczeń: kilka reperów wykazało większą różnicę w wartościach przemieszczeń w stosunku do pierwotnego podejścia o wartościach $\mathrm{w}$ przedziale $-9 \mathrm{~mm}-+3 \mathrm{~mm}$.

\section{INTRODUCTION}

The area of Inowroclaw is specific both in its mining and geological aspects. Although the area is considered as post mining (salt mining) area, there are ground deformations that can be observed. The terrain surface is affected by several factors diapirism (uplifts) and hydrogeological processes as subrosion (subsidence). A significant part of benchmarks demonstrates vertical displacements of positive values (uplifts), which are caused by halotectonics. This process relates to a specific geological structure - the presence of salt diaper, which is situated just below the city area. Due to the mining operations and the catastrophic effects of uncontrolled explorations at the beginning of the twentieth century a leveling network was established. Its area size and the number of its benchmarks was increasing by years. Most of the benchmarks were installed on the walls of heavy buildings. The Solno, the last company operating in Inowrocław was closed down and in 1995 regular leveling measurements were stopped. New surveys were of the area started in 2002 and a new research network with new control points was installed in the ground. Dozen of years of measurements provided different rates of height changes evaluated for new benchmarks, which were installed in the soil (ground benchmarks) and the old ones mounted on walls. As it turned out, it has made some problems in deformation analysis. Rates of ground deformations are taken into consideration in classification processes in master planning. The essential problem is in establishing what should be the criteria for the assessment of validity of the determined displacements demonstrated by the benchmarks. The significance of the problem of adjustment of leveling data to obtain "good" heights or displacements was discussed among others in the papers (Han et al. 2014; Malarski 2016; Wolski and Toś 2017; Wolski and Granek 2020).
So, it is with this problem in mind that the authors demonstrate the application of the apparent displacement method to determine the most consistent assessment of the degree of the displacements of the benchmarks.

\section{A BRIEF OUTLINE OF THE NATURAL CONDITIONS OF THE DEFORMATION PROCESS}

Due to the geoenvironmental specificity of the study area, also due to the long dilatation of the mining activity carried out there, despite its small size it has been the subject of many research works it in the field of geology, geomorphology, mine engineering, geodesy etc.

A large number of scientific papers have been devoted to the geological structure of the salt diapir (Poborski 1957; Bujakowski 1986; Poborska-Młynarska 1984) and to the effects of mining operations (Budryk 1933; Kortas 1996). The brief of the geological characteristics of the Inowrocław area which we now present is limited only to issues related to the ground deformation process observed there.

The shape of the salt diapir in Inowrocław resembles an ellipse in its horizontal projection (with the longer NS axis, about $3 \mathrm{~km}$ long, and the shorter WE one of $1 \mathrm{~km}$ length). It occurs in the zone of the moraine plain, which is distinguished by a lack of convex marginal forms (Fig. 1). The western and eastern walls of the dome lie steeply or almost vertically.

The salt dome is covered with Quaternary formations, in the northern part additionally also with Jurassic formations (often strongly dislocated). The top surface of the deposit, lying at a depth of 120-190 m, is covered with a gypsum cap with a thickness of 50 $-180 \mathrm{~m}$. The formations of the cap were formed as a result of the underground dissolution and erosion

Fig. 1. Inowrocław. The scheme of leveling network surveys carried out in 2005 and 2018 and vertical displacements of terrain surface for the period 2005-2018 obtained in the initial adjustment

Ryc. 1. Inowrocław. Schemat pomiarów sieci niwelacyjnej wykonanych w latach 2005 i 2018 oraz pionowe przemieszczenia powierzchni terenu w okresie 2005-2018 uzyskane na podstawie wstępnego wyrównania 


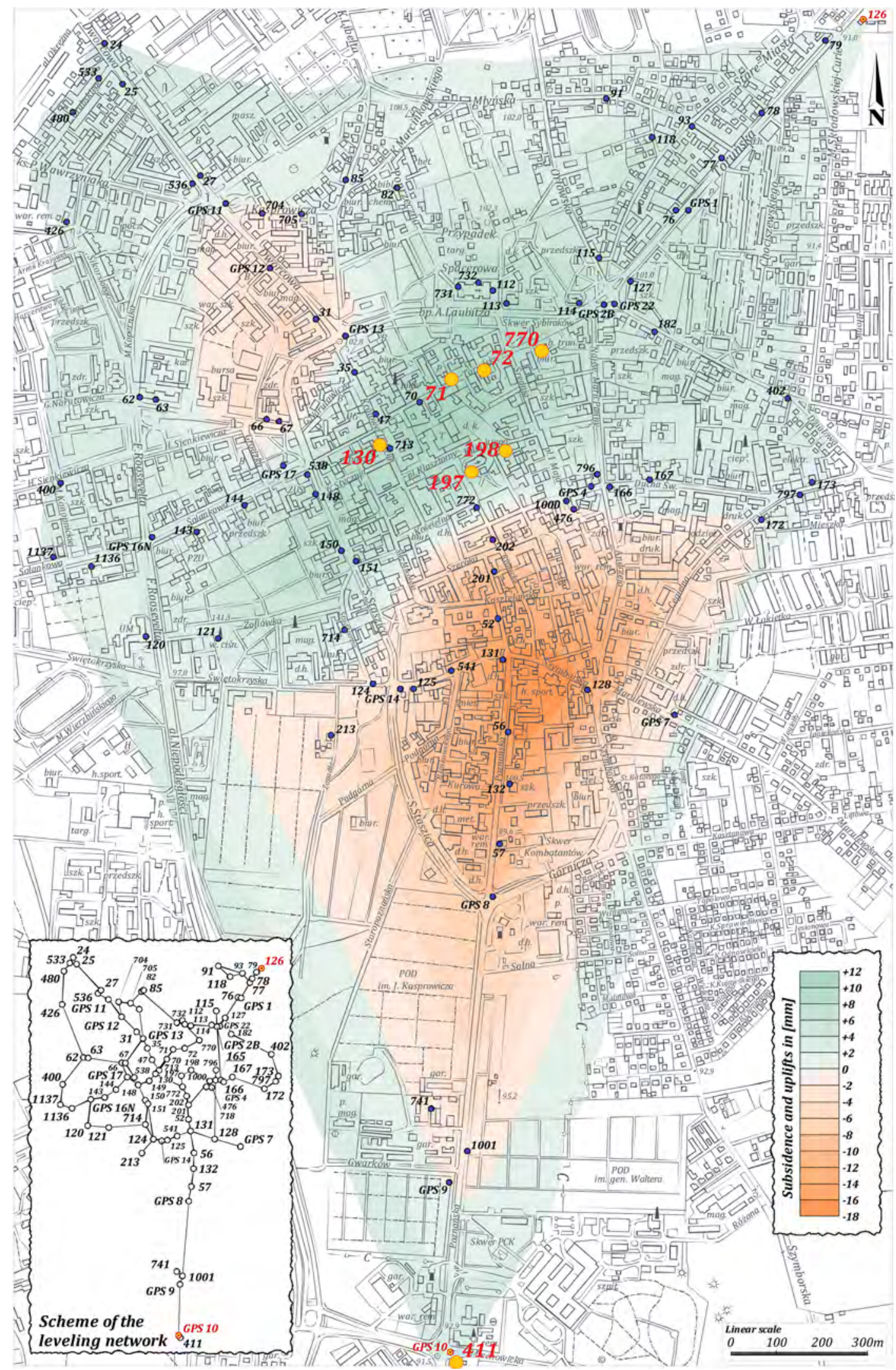


(subrosion) of water-soluble rocks and their removal as salt brines outside the deposit. The gypsum cap is thus a residue of selective dissolution due to the solutions circulating in the rock mass with an assured inflow of freshwater, mainly from the rocks of the overburden. Water migration results from the different density of solutions and is of a gravitational nature. This part of the salt structure is seen in the natural environment as the result of phenomena occurring in karst regions: underground drainage systems with sinkholes and caves. Ground deformations, which reveal underground processes and phenomena, were observed in Inowroclaw in historic times, many years before the era of mining.

The topographic surface of the dome is varied and the high variability that characterizes the altitude range of salt occurrence is caused by salt karst processes (Szczerbowski 2010). Over the course of over 100 years of mining activity, starting in in the end of nineteenth century the Inowrocław deposit was exploited using various methods of salt extraction and continuing until 1991. In general there were two stages in the history of the mining activity in the area: solution mining (usually with the use of natural saline water and brines) and shallow mining (taking place in underground at the top of the level of salt diapir).

These methods were usually uncontrolled, causing many collapses of the natural caves existing in the upper part of the deposit (cap rocks) and the sinkholes at the surface. In the 1930s a modern underground mine started to operate using a wet underground mining and chamber-pillar system. All mining activity was definitely stopped in 1991 when the mine was closed down and all mining excavations were filled up to prevent ground deformations and dissolution of the underground salt pillars. The ground deformations caused by the salt extraction carried out by The Solno mine were small: maximal values of the vertical displacements (subsidence) amounted to only approximately $20 \mathrm{~cm}$.

In fact the height changes of a control points, observed results obtained from the use of the geodetic surveys carried out in the area for many years resulted from a subrosion process, the effects of the mining and of the natural movement of the salt masses upwards. During the period, when the mining operations were taking place, subsidence was a dominant effect on the overall picture of altitude changes, and the effect of the uplift processes remained.
The subrosion process results in a degradation of the salt diapir because of hydrogeological changes in the rock mass. They cause all kinds of leaching of the salt, leading to the formation of weakness zones in the rock mass, whose the mechanical properties are significantly lower. They also cause a system of caverns, which were penetrated by miners in old times. The sinkholes formed on the surface are the result of this natural process. Mining activity, however, intensified the migration of deep water, with the result that at the beginning of the $20^{\text {th }}$ century, a series of catastrophic sinkholes appeared in the town. The visible traces of deformation from that period are still visible today in the presence of numerous empty squares in the town, which have been deemed to be unsuitable for development. This movement related to the migration of the natural underground brine dissolving rock salt and was observed in times of old mining activities, when it was carried over a small size of area in the southern part of the deposit (Budryk 1933; Szczerbowski 2005). The phenomenon occurs due to the leaching of salt on the rock salt top surface and on in the cap deposits and as a result of the solutions circulating in the rock mass a loss of soluble components occurs, and these components are carried away in this degradation process beyond the dome. Based on the relevant calculations, K. Poborska-Młynarska (1984) determined an annual leaching degree of $6 \mathrm{~mm}$ per unit area, noting at the same time that the given value may be higher due to the accompanying processes. The loss of rock mass in the vertical profile does not have necessarily to reveal itself directly as ground subsidence. But the direct effect of the process is the salt karst phenomena which is the main cause of the sinkholes which had been observed on the surface many years before (the last in 2003). Moreover, the factor compensating for the subsidence of the top surface of the salt diapir is an uplifting resulted from a secondary crystallization of the gypsum and rock salt from the circulating saline water and the halokinetic movement of the salt masses upwards.

A consideration of both the geological conditions and the mining activities carried out in the salt deposit are important from the point of view of the observed deformation of the land surface but with the decreasing influence of the old mining exploitation the outline of vertical displacements, which more and more reveal the effects of natural processes, becomes more varied.

Ground surface movements roughly reflect the contemporary tectonic activity of the Inowrocław salt 
structure. The performance of the vertical displacements of the benchmarks of the research network for the last quarter-century shows its significant mobility. The results of measurements were discussed in the context of the state the tectonic mobility of the area and the geological structure of the dome. Unusual agreement in the rates of geological processes (salt diapir uplift) determined by geodetic measurements and estimated by geological methods over a long period of time confirms the accuracy of previous ideas about the contemporary diapir movements of the Inowrocław Salt Dome. The repeated leveling evaluated for the lat two time intervals has provided similar regions and rates of uplifts, giving an additional support of consistency of the measurements. These evaluations have been a the result of the lowering of the salt mirror as a result of the effect of its natural degradation, and also taking in consideration the influences of exploitation (with various methods. (Szczerbowski and Gawałkiewicz 2005; 2020).

\section{GEODETIC MEASUREMENTS}

The oldest leveling in Inowrocław was carried out by Caville in 1894, the next in 1905 by Weinreich, but the valuable measurements, from which the results are available to us were performed in 1913 (Kortas 1996). In 1956, the intensification of the mining exploitation of the salt deposit and the development of the subsidence basin made it necessary to expand the observation network with new points (Tarczyński 1984). The leveling network covered the entire town of Inowrocław and large adjacent areas. The design of the leveling network included two levels of leveling: basic and filling. The maximum possible number of benchmarks from the leveling from 1913 and 1933 (Szpetkowski 1959) was included in the network. Measurements were connected to four benchmarks considered as reference points. The measurements were made by the use of a precise leveling method carried out at annual intervals, although from 1973 the entire network was observed every 2 years. In 1978 the existing network was expanded with new points covering the entire area of mining influence, thus creating a modern network of points, many of which, unfortunately, no longer exist.

In 1986 subsequent to governmental decision to closure the mine and a process of flooding its workings began. This process was finally completed in 1991. Thus, mining activities in the area of Inowrocław were finally terminated. The leveling measurements showed an almost complete cessation of ground surface subsidence. These leveling measurements, performed in 1995, were the last o be carried out under the mine's authority.

In the years 2002, 2004, 2005 and 2018, research was conducted in order to actually stop surface movements in Inowrocław (Szczerbowski 2004; 2005; 2007). In 2002, a research network with 17 earth benchmarks was established. These so-called geodynamic points were additionally applied in GPS and gravimetric measurements. In this way, the old mining network was enhanced with benchmarks installed in the ground. Currently, several of these benchmarks have been destroyed, the remaining ones are the only ground points used in precise leveling measurements which are taken for analysis of any deformation of terrain surface in Inowrocław.

In the years 2002-2018, the measurements were carried out on nearly 100 benchmarks, which cover about $2.5 \mathrm{~km}^{2}$ of the area of the town, and the total length of the leveling sections was usually over $20 \mathrm{~km}$. The results of the benchmark height measurements were verified with additional observations on selected sections.

Moreover, as it was mentioned the ground benchmarks were applied in GPS measurements of height changes (vertical displacements), and the GPS sessions ensured the appropriate accuracy of the determined heights (related to the point 3403 of the POLREF network). I should be pointed out that leveling measurements were always made with reference to points located outside the former mining area of the Solno mine.

As part of the last campaign carried out in 2018, the number of benchmarks involved in the measurements was clearly smaller. The reasons for the loss of geodetic marks are mainly the result of the renovation and reconstruction of the facades of buildings. However, heights were determined for 80 benchmarks in the town: over 70 wall benchmarks and several ground points (socalled geodynamic, GPS series). The measurements covered nearly $2.4 \mathrm{~km}^{2}$ of the town of Inowrocław, and the length of the leveling lines were approximately $18 \mathrm{~km}$.

The benchmark stability analysis is based on the rigorous adjustment of the leveling network with a benchmark placed in its central part, which is assumed as the reference benchmark. It should be as close as possible to the geometric center (centroid) of the figure formed by the network points. This procedure can be repeated 
by adopting another point from the central part of the area. In this way, errors of the determined heights of the benchmarks are calculated by minimizing the total length of the leveling sections in relation to the reference benchmark (due to its central position). It is crucial to determine the most reliable values of vertical displacements. It should be noted that the determined displacement values are often close to the values of the error of their determination, hence a method of apparent displacements is applied. The method has been discussed in some manuals devoted to the elaborations of surveying results (Bryś and Przewłocki 1998; Prószyński and Kwaśniak 2006).

Due to the initial alignment of the leveling results obtained in measurements of 2018 the maximum error of the point height was $\mathrm{m}_{\mathrm{H}}= \pm 1.30 \mathrm{~mm}$ and the average error $m_{H}($ mean $)= \pm 0.94 \mathrm{~mm}$. The distant points were considered as reference benchmarks in rigorous adjustment: 126 and GPS10. The same points were considered as reference benchmarks in an adjustment of the measurements of 2005. Similar values of the errors were obtained in previous measurements carried out in the period of 2002-2004. The values of the heights were expressed in the Amsterdam normal height system.

The values of vertical displacements of the $i$-th point in time interval 2005-2018 were determined from the relationship:

$$
\Delta \mathrm{H}_{\mathrm{i}}=\mathrm{H}_{\mathrm{i}}^{2018}-\mathrm{H}_{\mathrm{i}}^{2005}
$$

and the mean errors of the vertical displacement of the i-th point from the formula:

$$
\mathrm{m}_{\Delta \mathrm{Hi}}= \pm \sqrt{\mathrm{m}_{\mathrm{H}_{\mathrm{i} 2005}}^{2}+\mathrm{m}_{\mathrm{H}_{\mathrm{i} 2005}}^{2}}
$$

The average value of error of the displacement evaluated for the 2005-2018 period in the initial adjustment amounted to a value of $\mathrm{m}_{\Delta \mathrm{H}}= \pm 1.34 \mathrm{~mm}$.

In the new approach the point of 130 ID was considered as the reference benchmark due to its location (nearly centroid) and the small value of the calculated error. The In calculation $\mathrm{H}=100 \mathrm{~m}$ was presumed as its provisional height. The rigorous adjustment was made with an application of the leveling data obtained in the measurements carried out in 2005 and in 2018. As the result of all this data the calculations were able to provide provisional (relative) heights of the points and their errors
According to the apparent displacement method and proceeding from on the basis of the calculations, the values of the vertical displacements were verified (checking the consistency criterion), assuming that the permissible height difference from the two independently aligned measurements must meet the criterion:

$$
\left|\Delta \mathrm{H}_{\mathrm{i}}\right| \leq \mathrm{k} \cdot \mathrm{m}_{\Delta \mathrm{Hi}}
$$

where:

$\mathrm{k}-$ - significance coefficient (assumed $\mathrm{k}=2$ for the statistical significance $\alpha=0.05$ ).

$\mathrm{m}_{\triangle \mathrm{H} 2005-2018}$ - average apparent error of the vertical displacement of the $i^{\text {th }}$ benchmark.

Moreover,

- the average error of apparent vertical displacement in in measurements of the 2005 survey campaign was $\pm 0.78 \mathrm{~mm}$;

- the average apparent error of vertical displacement in in measurements of the 2018 survey campaign was $\pm 0.66 \mathrm{~mm}$;

The analysis of the constancy of points in the network using the apparent displacement method shows that out of the 77 points measured in total of both of the survey campaigns, the assumed criterion meets 7 points:

$$
\begin{aligned}
& \left.411\left(\mathrm{H}_{2009}=87.81692 \mathrm{~m}\right), \mathrm{m}_{\mathrm{DH}}= \pm-1.88 \mathrm{~mm}\right), \\
& \left.770\left(\mathrm{H}_{2009}=95.72974 \mathrm{~m}\right), \mathrm{m}_{\mathrm{DH}}= \pm-0.81 \mathrm{~mm}\right), \\
& \left.197\left(\mathrm{H}_{2009}=97.94204 \mathrm{~m}\right), \mathrm{m}_{\mathrm{DH}}= \pm-0.6 \mathrm{~mm}\right), \\
& \left.198\left(\mathrm{H}_{2009}=95.71018 \mathrm{~m}\right), \mathrm{m}_{\mathrm{DH}}= \pm-0.41 \mathrm{~mm}\right), \\
& \left.72\left(\mathrm{H}_{2009}=94.58602 \mathrm{~m}\right), \mathrm{m}_{\mathrm{DH}}= \pm 0.33 \mathrm{~mm}\right), \\
& \left.130\left(\mathrm{H}_{2009}=100 \mathrm{~m}\right), \mathrm{m}_{\mathrm{DH}}= \pm 0.73 \mathrm{~mm}\right), \\
& \left.71\left(\mathrm{H}_{2009}=95.13187 \mathrm{~m}\right), \mathrm{m}_{\mathrm{DH}}= \pm 1.33 \mathrm{~mm}\right) .
\end{aligned}
$$

Following on from these results these consistent points were taken in further adjustment as the reference benchmarks. The results of the calculations for points selected as a sample are presented in Tab. 1.

On this basis, the apparent displacements $\mathrm{H}_{\mathrm{i}} 2005-$ 2018(S) were transformed to a new reference level according to the relationship:

$$
\mathrm{S}=\frac{1}{u} \cdot \sum_{i=1}^{u} \Delta H_{2005-2018}
$$

$S$ - the displacement (shift) of reference level

$(\mathrm{S}=-\mathbf{0 , 7 3} \mathrm{mm}$ );

$u$ - the number of consistent points fulfilling criterion $(\mathbf{u}=7)$. 
Tab. 1. Outcomes of the first step in the calculation by the apparent displacements method of leveling results carried out in Inowrocław in 2005 and 2018

Tab. 1. Wyniki pierwszego etapu obliczeń z zastosowaniem metody przemieszczeń pozornych dla wyników pomiarów niwelacyjnych zrealizowanych w Inowrocławiu w latach 2005 i 2018

\begin{tabular}{|c|c|c|c|c|c|c|c|c|}
\hline $\begin{array}{l}\text { Point's } \\
\text { ID }\end{array}$ & $\begin{array}{c}\mathrm{H} 2005 \\
{[\mathrm{~m}]}\end{array}$ & $\begin{array}{l}\mathbf{m}_{\mathrm{H} 2005} \\
{[\mathbf{m m}]}\end{array}$ & $\begin{array}{c}\text { H2018 } \\
{[\mathrm{m}]}\end{array}$ & $\begin{array}{l}\mathbf{m}_{\mathrm{H} 2018} \\
{[\mathrm{~mm}]}\end{array}$ & $\begin{array}{l}\mathrm{DH}_{2005-2018} \\
{[\mathrm{~mm}]}\end{array}$ & $\begin{array}{c}\text { Average } \\
\text { apparent error } \\
\mathbf{m}_{\Delta \mathrm{H} 2005-2018} \\
{[\mathrm{~mm}]}\end{array}$ & 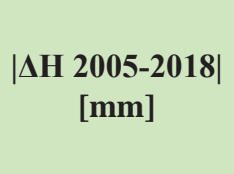 & $\begin{array}{c}\text { State of } \\
\text { consistency }\end{array}$ \\
\hline GPS8 & 94.04646 & 0.88 & 94.02806 & 0.77 & -18.40 & 1.17 & 18.40 & not consistent \\
\hline GPS9 & 90.99258 & 1.27 & 90.98149 & 0.98 & -11.09 & 1.60 & 11.09 & not consistent \\
\hline GPS13 & 98.39267 & 0.72 & 98.36091 & 0.51 & -31.76 & 0.88 & 31.76 & not consistent \\
\hline 25 & 91.76907 & 0.97 & 91.76266 & 0.82 & -6.41 & 1.27 & 6.41 & not consistent \\
\hline 27 & 95.71684 & 0.91 & 95.70748 & 0.73 & -9.36 & 1.17 & 9.36 & not consistent \\
\hline 31 & 98.89677 & 0.76 & 98.88018 & 0.58 & -16.59 & 0.96 & 16.59 & not consistent \\
\hline 52 & 100.66176 & 0.65 & 100.63652 & 0.54 & -25.24 & 0.85 & 25.24 & not consistent \\
\hline 57 & 95.32406 & 0.88 & 95.30468 & 0.73 & -19.38 & 1.14 & 19.38 & not consistent \\
\hline 62 & 94.45710 & 0.8 & 94.44831 & 0.7 & -8.79 & 1.06 & 8.79 & not consistent \\
\hline 63 & 94.72740 & 0.79 & 94.72002 & 0.69 & -7.38 & 1.05 & 7.38 & not consistent \\
\hline 66 & 95.61411 & 0.67 & 95.59973 & 0.61 & -14.38 & 0.91 & 14.38 & not consistent \\
\hline 67 & 96.36192 & 0.69 & 96.34662 & 0.58 & -15.30 & 0.90 & 15.30 & not consistent \\
\hline 71 & 95.13127 & 0.49 & 95.13187 & 0.36 & 0.60 & 0.61 & 0.60 & consistent \\
\hline 72 & 94.58642 & 0.54 & 94.58602 & 0.46 & -0.40 & 0.71 & 0.40 & consistent \\
\hline 77 & 91.53643 & 0.8 & 91.52784 & 0.73 & -8.59 & 1.08 & 8.59 & not consistent \\
\hline 78 & 89.67648 & 0.86 & 89.66576 & 0.79 & -10.72 & 1.17 & 10.72 & not consistent \\
\hline 79 & 87.96662 & 0.93 & 87.95533 & 0.87 & -11.29 & 1.27 & 11.29 & not consistent \\
\hline 126 & 86.11775 & 0.97 & 86.10384 & 0.89 & -13.91 & 1.32 & 13.91 & not consistent \\
\hline 130 & 100.00000 & $\mathbf{0}$ & 100 & $\mathbf{0}$ & 0.00 & 0.00 & 0.00 & consistent \\
\hline 411 & 87.81953 & 1.39 & 87.81692 & 1.09 & -2.61 & 1.77 & 2.61 & consistent \\
\hline & average $=$ & 0.78 & average $=$ & 0.66 & & \multicolumn{2}{|c|}{ number of consistent points $=$} & 7 \\
\hline & & & & & & \multicolumn{2}{|c|}{ number of not consistent points $=$} & 70 \\
\hline & & & & & & & sum $=$ & 77 \\
\hline & & & & & & \multicolumn{2}{|c|}{$S-$ reference level shift $=$} & -0.73 \\
\hline
\end{tabular}


Tab. 2. Final outcomes of the first step calculation by the apparent displacements method of leveling results carried out in Inowrocław in 2005 and 2018

Tab. 2. Ostateczne rezultaty obliczeń z zastosowaniem metody przemieszczeń pozornych dla wyników pomiarów niwelacyjnych zrealizowanych w Inowrocławiu w latach 2005 i 2018

\begin{tabular}{|c|c|c|c|c|c|c|}
\hline Point's ID & $\mathbf{H}_{2005}$ & $\mathbf{m}_{\mathrm{H} 2005}$ & $\mathbf{H}_{2018(\mathrm{~S})}$ & $\mathbf{m}_{\mathrm{H} 2018}$ & $\Delta \mathbf{H}_{2005-2018(\mathrm{~S})}$ & $\begin{array}{c}\text { Displacements } \\
\text { reduced by } T\end{array}$ \\
\hline GPS8 & 94.04646 & 0.88 & 94.03063 & 0.98 & -15.83 & -5.92 \\
\hline GPS9 & 90.99258 & 1.27 & 90.98524 & 0.79 & -7.34 & 2.57 \\
\hline GPS 13 & 98.39267 & 0.72 & 98.36039 & 0.94 & -32.28 & -22.37 \\
\hline 25 & 91.76907 & 0.97 & 91.76220 & 1.52 & -6.87 & 3.04 \\
\hline 27 & 95.71684 & 0.91 & 95.70699 & 1.35 & -9.85 & 0.06 \\
\hline 31 & 98.89677 & 0.76 & 98.87965 & 1.06 & -17.12 & -7.21 \\
\hline 52 & 100.66176 & 0.65 & 100.63801 & 0.80 & -23.75 & -13.84 \\
\hline 57 & 95.32406 & 0.88 & 95.30704 & 0.97 & -17.02 & -7.11 \\
\hline 62 & 94.45710 & 0.80 & 94.44798 & 1.29 & -9.12 & 0.79 \\
\hline 63 & 94.72740 & 0.79 & 94.71968 & 1.27 & -7.72 & 2.19 \\
\hline 66 & 95.6149 .91 & 0.67 & 95.59936 & 1.12 & -14.75 & -4.84 \\
\hline 67 & 96.36192 & 0.69 & 96.34624 & 1.06 & -15.68 & -5.77 \\
\hline 71 & 95.13127 & 0.49 & 95.12994 & 0.00 & -1.33 & 8.58 \\
\hline 72 & 94.58642 & 0.54 & 94.58609 & 0.00 & -0.33 & 9.58 \\
\hline 77 & 91.53643 & 0.80 & 91.52965 & 1.19 & -6.78 & 3.13 \\
\hline 78 & 89.67648 & 0.86 & 89.66756 & 1.30 & -8.92 & 0.99 \\
\hline 79 & 87.96662 & 0.93 & 87.95713 & 1.47 & -9.49 & 0.42 \\
\hline 126 & 86.9 .91775 & 0.97 & 86.10564 & 1.52 & -12.11 & -2.20 \\
\hline 130 & 100.00000 & 0.00 & 99.99927 & 0.00 & -0.73 & 9.18 \\
\hline \multirow[t]{2}{*}{411} & 87.81953 & 1.39 & 87.82141 & 0.00 & 1.88 & 11.79 \\
\hline & average $=$ & 0.78 & average $=$ & 0.99 & & \\
\hline
\end{tabular}

The last stage of the procedure was to determine "real" displacements after a shift operation. The value of the shift (T) was assumed as $9.9 \mathrm{~mm}$ and it was calculated as being the average value of the differences between the values of the apparent displacements and values calculated in an initial adjustment:

$$
\mathrm{T}=\Delta \mathrm{H}_{\mathrm{i} 2005-2018}-\Delta \mathrm{H}_{\mathrm{i} 2005-2018(\mathrm{~S})}
$$

So, this strict alignment provided new values for the displacements considered to be the most probable. The results of this stage of procedure are presented in Tab. 2 .

The average value of the displacement error evaluated in adjustment of this method is $\pm 1.02 \mathrm{~mm}$. It is clearly less than in the initial adjustment $( \pm 1.34 \mathrm{~mm})$. Considering the obtained values of the displacements it is easy do determine points which demonstrated deviation in the values of the displacements calculated in the initial adjustment and also by the apparent displacements method. The results of the comparative analysis are presented in Fig. 2. The vast majority of the points 


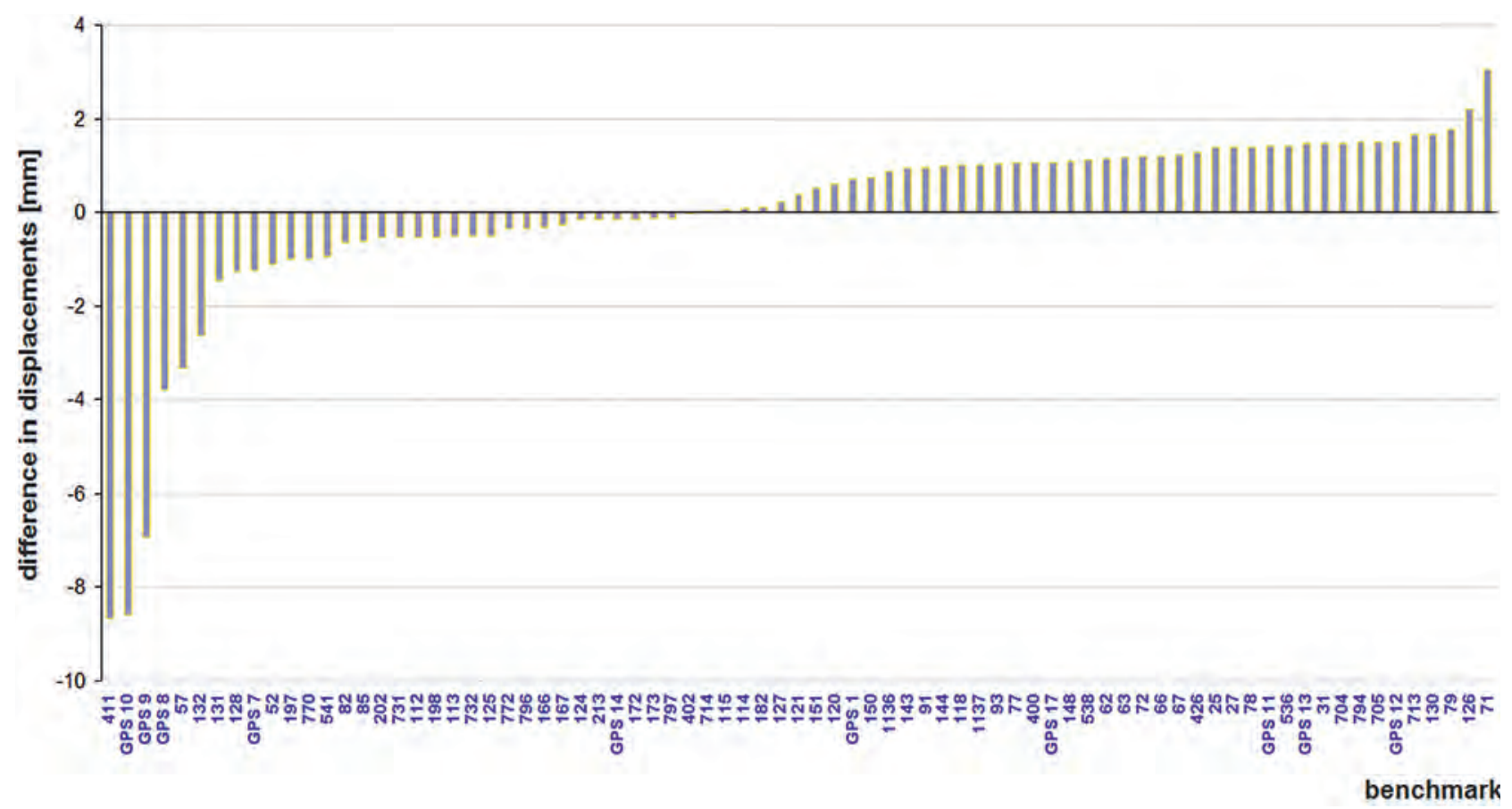

Fig. 2. Differences between the corrected and primary calculated values of the vertical displacements of selected benchmarks (Ddh)

Ryc. 2. Różnica między skorygowanymi a pierwotnie obliczonymi wartościami przemieszczeń pionowych wybranych reperów (Ddh)

show deviation of the values within range of the error. However there are points, which determined displacements clearly deviate from values assumed as the most probable, i.e. obtained by the apparent displacements method: $71(3.06 \mathrm{~mm}), 126(2.2 \mathrm{~mm}), 132(-2.63 \mathrm{~mm})$, $57(-3.34 \mathrm{~mm})$, GPS $8(-3.79 \mathrm{~mm})$, GPS $9(-6.93 \mathrm{~mm})$, GPS $10(-8.6 \mathrm{~mm}), 411(-8.66 \mathrm{~mm})$. So it can be seen that the benchmarks 126 and GPS10, assumed as reference points in the initial adjustment, were displaced in fact. The distribution of differences between displacements obtained in the both methods is presented in a form of a map on Fig. 3.

However, the new approach in adjustment doesn't influence to any great extent the spatial distribution of the displacements.

\section{FINIAL REMARKS}

The noticeable development of leveling instruments used fro survey operation and measurement data processing (digital electronic level is a standard for instruments used at present) has as led to better precision, accuracy and reliability of results in the determination of heights. The demand for a high-quality vertical positioning of points is required in many fields and for many applications. One of these is for the determination of ground displacements in urban areas. It involves the use of proper measurements, consistent reference benchmarks, correct adjustments etc.

This study proposes an approach in adjustment calculations known as the apparent displacement method. Despite the fact that the standard adjustments provided results (vertical displacements of points) with high accuracy (small errors of determined displacements), we fell that an application of the method for adjusting a level network was made them much better. So, thanks to the numerical results of the method, the vertical displacement signals demonstrated by benchmarks in a level network in Inowrocław have become much more validated. Thanks to the method the point considered as reference were recognized as unstable. For The vast majority of the points difference between the displacements obtained o the base of the standard approach and those calculated by the apparent displace- 


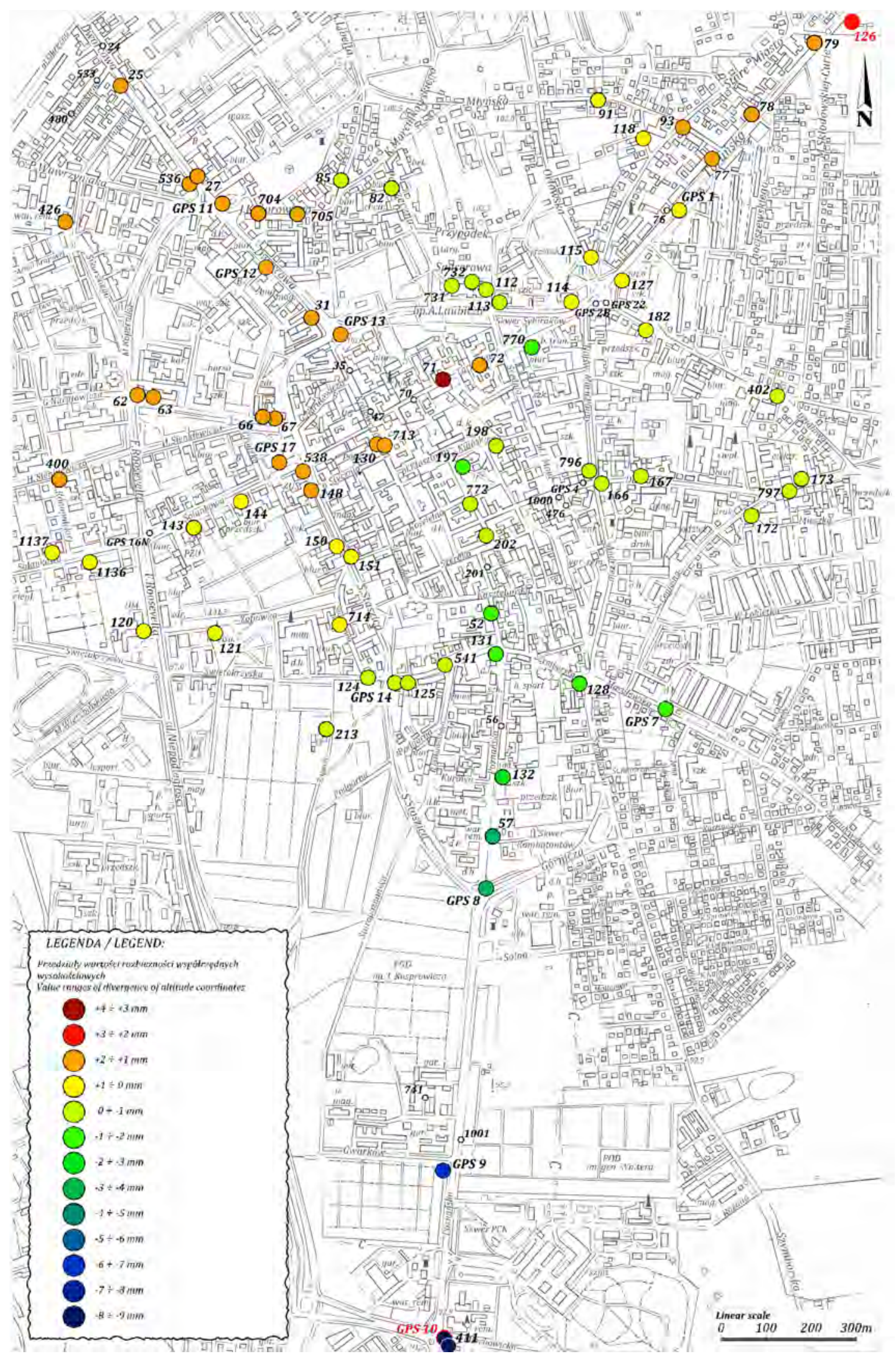


ments method is minimal (from $-1.5 \mathrm{~mm}$ to $+1.5 \mathrm{~mm}$ ). Several points demonstrated higher difference ranging in the interval $-9 \mathrm{~mm}-+3 \mathrm{~mm}$.

The results presented in this case study show that the proposed approach can properly depict the displacements and minimize the inconsistencies between previously elaborated heights and inconsistencies of points the considered as reference benchmarks.

\section{REFERENCES}

1. Budryk W. 1993. Zapadliska na terenie miasta Inowrocławia, Przegląd Górniczo-Hutniczy Nr 8.

2. Bryś H., Przewłocki S. 1998. Geodezyjne metody pomiarów przemieszczeń budowli. Wydawnictwo PWN. Warszawa.

3. Bujakowski W. 1986. Kartograficzne opracowanie północnej części wysadu solnego Inowrocławia. Kwartalnik ZN AGH, nr 10.

4. Han J.Y., Hwang, C., Chou, J.Y., Hung, W.C. 2014. Time-Variant Adjustment for a Level Network. Journal of Surveying Engineering. 140, pp. 04014004_1-04014004_7.

5. Kortas G. 1996. Całokształt wpływów działalności górniczej dla ustalenia stref zagospodarowania miasta Inowrocławia. Kraków. Materiały niepublikowane. Archiwum IKS „Solino".

6. Malarski R. 2016. A concept for the examination of reference points stability in horizontal control networks. Reports on Geodesy and Geoinformatics 101 (1), pp. 60-69.

7. Poborska-Młynarska K. 1984. Naturalna degradacja wysadu solnego w Inowrocławiu. Kwartalnik Geologiczny, t. 28, nr 2.

8. Poborski J. 1957. Wykształcenie czapy gipsowej i rozwój zjawisk krasowych na wysadzie solnym w Inowrocławiu. Archiwum Górnictwa, t. II, z. 4.

9. Prószyński W., Kwaśniak M., 2006. Podstawy geodezyjnego wyznaczania przemieszczeń. Oficyna Wydawnicza Politechniki Warszawskiej. Warszawa.
10. Szczerbowski Z. 2004. Preliminary results of geodetic measurements in the Inowrocław salt dome area, central Poland. Annales Societatis Geologorum Poloniae. Krakow, pp. 319-324 .

11. Szczerbowski Z. 2005. Initial Interpretation of Post-mining Movements of the Surface in the Area of Inowrocław. Archives of Mining Sciences, Vol. 50, Issue 2, pp. 235-249.

12. Szczerbowski Z. 2007. The evaluation of salt dome vertical movements in Inowrocław detected by classical precise levelling and GPS surveying techniques. Acta Geodynam. Geomat., 4, 4 (148), pp. 1-10.

13. Szczerbowski Z. 2010. The use of land information system in geomorphostructural analysis on the example of Inowrocław. Acta Geodynamica et Geomaterialia, Vol. 7, No. 2 (158), pp. 153-166.

14. Szczerbowski Z., Gawałkiewicz R. 2005. Użyteczność geodezyjnych pomiarów w diagnostyce zabytkowych obiektów na przykładzie kościoła w Inowrocławiu. Przegląd Budowlany: miesięcznik Polskiego Związku Inżynierów i Techników Budownictwa. 2, pp. 22-28.

15. Szczerbowski Z., Gawałkiewicz R. 2020. Współczesne ruchy wysadu solnego Inowrocławia w świetle badań geodezyjnych. Przegląd Geologiczny. 3.

16. Szpetkowski S. 1959. Ekspertyza dla żupy solnej w Inowrocławiu dotycząca analizy wyników prac pomiarowych wykonanych w związku z głębieniem szybu Solno II, Kraków, Materiały niepublikowane. Archiwum IKS „Solino".

17. Tarczyński R. 1984. Analiza dotychczasowych wpływów eksploatacji na górotwór i powierzchnię na podstawie obserwacji geodezyjnych i przebiegu eksploatacji. Kraków. Materiały niepublikowane. Archiwum IKS „Solino”.

18. Wolski B., Granek G. 2020. Functionality and reliability of horizontal control net (Poland), Open Geosciences; T. 12/1, pp. 668-677.

19. Wolski B., Toś C. 2017. A Probabilistic Model of Assessment of Level Network Functionality. Geomatics and Evironmental Engineering, Vol. 11/2, pp. 73-83.

Fig. 3. The spatial distribution of differences between the corrected and primary calculated values of the vertical displacements of the benchmarks

Ryc. 3. Rozkład przestrzenny różnic pomiędzy skorygowanymi a pierwotnie obliczonymi wartościami przemieszczeń pionowych reperów 